\title{
PAUL'S USE OF THE PSALMS. BEYOND MIDRASH
}

\author{
JOHN K. STAFFORD* \\ University of Manitoba
}

\begin{abstract}
The Psalms are the most cited portions of Scripture in the New Testament. This paper investigates Paul's use of the Psalms and seeks to answer the concern that his citation strategy is both arbitrary and self-serving. Inasmuch as it has sometimes been concluded that Paul, in midrashic fashion, forced his citations to say something contrary to a more natural reading. This paper suggests that Paul uses citation criteria very carefully. Preliminary results point to the use of texts that lie well within their natural reading, yet exegeted in such a way that the resulting exegesis is folded back into the text as the apostle cites it. Thus rather than citing texts arbitrarily, Paul uses great skill and sophistication in selecting and utilising texts with exegetical precision. In so doing, Paul is not using midrash but may actually be developing a characteristically Christian approach to the citation of sacred text.
\end{abstract}

KEY WORDS: LXX, Paul, Psalms, Scripture quotations, Midrash, New Testament

The use of the Old Testament in the New has always attracted considerable scholarly attention because of the varying degrees of fidelity the New Testament writers use when invoking the Old Testament. Assessing the implications of this has resulted in a variety schemes which attempt to associate Old Testament quotations with midrashic, pesher, and targumic methods used by the rabbis, with the easy adoption of them by early Christian expositors and theologians during the formation of the New Testament texts we now possess.

Allowing for the possibility that such variations from both the extant LXX, proto-MT and Dead Sea Scrolls witnesses, not all departures from the available exemplars can be attributed to a different Vorlage. Simple Tendenz is naturally a factor because a Christological reading of the Hebrew Scriptures was demanded by the known teaching and polemic of Jesus who presented himself in relation to the existing sacred traditions of Israel and its Torah. The question however, is whether the church and its kerygma, in presenting their account and understanding of Jesus, did so by using texts beyond any reasonable reading of them even using

* JOHN K. STAFFORD (PhD, University of Manitoba) is associate professor in Biblical Studies at Providence University College, within the University of Manitoba. His teaching fields are Introduction to the Pentateuch, Homiletics, History of Liturgy, and Interpreting Old Testament Narrative. 
known and accepted methods of exegesis—midrash and pesher-which could not support later scrutiny thus diminishing their overall usefulness to the convictions of later generations. Having opened such a door, could more spectacular exegesis be far away! Regardless, it would be surprising if there was not some re-shaping of exegetical method beyond the normal bounds of text-fulfillment techniques observable in pesher, for example. The impact of such a reality upon the early church's handling of texts was, I suggest, gradual and informed by methods already current but at least critically open to its own developing convictions.

The goal of this paper is to investigate the possibility that Paul used texts in ways variously consistent with midrashic and targumic traditions of reading, yet doing so in ways that depart constructively from them. I suggest he does this by restraining his interpretations with what we might now call authorial intent, albeit a reading strategy that has sometimes failed the test of popularity in postmodern times.

We might also expect some indications that Paul's exegetical and citation methods might be as imaginative and creative as midrash or pesher. In addition, he may also adopt (or create) a broader emergent Christian way of citing texts even if those distinctives were short-lived as allegory rose to prominence. The radical nature of Paul's conversion clearly had an overwhelming impact on his intellect as well as his spiritual commitments. Still, for a modern readership, the integrity of how ancient texts were pressed into confessional service to make or uphold a case, is relevant for our consideration. Modern readers frequently fail to make the same connections the biblical writers made with their sources and, this being so, gives the appearance of special pleading on the part of the biblical authors and the sense that one is correct in seeing proof texts everywhere in the New Testament. This produces a cascading descent into the belief that the church, cumulatively, was making up its textual evidence, through semantic associations, literary echoes and so on, as it went along and in the New Testament, we have all the proof we need for strained (and thereby unconvincing) readings. Or, can we say that what we have is an emergent Christian midrash that supplied another characteristic method that includes what we might call "citation control"? I shall argue for the latter and suggest that the logic that supplies both the selection and use of a text for kerygmatic purposes may have been controlled much less by a process of simple idea association than by a genuine attempt to get behind the original intention of that text-original intention being the control set. Whether or not we deem the effort successful is perhaps less crucial than that it seems to have happened at all. For if it did, special pleading or proof texting on the part of the New Testament writings is much less likely. This being the case, the authoritative and controlling use and necessity of the Scriptures in the New Testament takes on a pivotal role not merely in terms of its evident ontological status (one might say), but also to develop an outlook that takes on a more recognizably scholarly dimension insofar 
as its goal is defensible Christological conclusions based on a measure of rigour and therefore less appearance of arbitrariness.

Significant in this regard is the nature of the new questions being asked by Jewish Christian believers about Israelite piety, religious tradition, and future expectation. The intensity of such questions arising from the matrix of experiences and debates occasioned by the life of Jesus of Nazareth most naturally pressed not only the place of Scripture in that Life, but also the manner of its use. The special traditions recorded by Luke draw very particular attention to this and stimulated in his church a hermeneutic of citation, not because of curiosity but because of Christological precedent-the absolutely new situation required a significantly new and meticulous handling of Hebrew Scripture, obviously in continuity with it but refocused. Thus, the New Testament writers were never concerned to resolve intriguing questions regarding scriptural riddles, anomalies, or apparent contradictions. The Genesis Apocryphon, for example, attempted to deal with the problematic union of Abraham and Sara, an affinity prohibited by Leviticus, and about which canonical Genesis is circumspect. The Apocryphon anticipated the problem and tried to provide a solution which satisfied the authority and consistency of the canon by clarifying a serious problem. In the standard Cambridge History, for example, C. F. Evans considers the use of Psalm 8 in Hebrews 2 to be a form of pesher in which select parts of the Psalm provided the required exegetical outcome for the author's purposes. ${ }^{1}$ As pesher, the Psalm becomes a fulfillment text though Evans does not say what the differences might be in pesher "forms". It is difficult to avoid the sense that any text using associative language might have done the job. The modern interpreter now has the rich tools of socio-rhetorical criticism which allow texts to speak more fully on their own terms and should result in greater sympathy looking back from our vantage point. It provides us with a serious check against anachronistic readings and possible dismissive conclusions about the formation of the church's most primitive texts. Still, the concern places some strain on the modern reader because it appears that a massive ideological demand was placed on relatively few texts with the sense that the New Testament writers drove many canonical texts into contexts never intended for them. And have the New Testament writers simply taken over an accepted use of textuality? Thus does the tendentious use of texts, assuming no radically different Vorlage, automatically result in linkages so imaginative that they become devoid of any real kerygmatic value outside the community that created them, especially if the quotations are free-form or mainly allusive to varying degrees?

The Christian appeal to Scripture resided in the traditions of both Israel and Jesus and raised the question of how best to handle ancient texts, formative as they were for Jesus and yet internally subversive of the traditions that gave rise to

1 C. F. Evans, "The New Testament in the Making", in The Cambridge History of the Bible, volume 1, ed. by P. R. Ackroyd (Cambridge: Cambridge University Press, 1980), 262.

PERICHORESIS $11.2(2013)$ 
them. Midrash, as it was variously practiced, I suggest, was insufficient to describe and explain the new reality in terms of its explication of Scripture, and too tightly constrained in the types of questions in which it was interested. This provided the first Christians with a kerygmatic and scholarly challenge-to handle existing texts responsibly in such a way that arbitrariness was avoided, their existing authority upheld, so that their apologetic and dogmatic use could be credibly utilized as a persuasive kerygmatic witness to Christ and a textual resource for the common life of the ecclesia.

This situation was intensified by the reading strategies observable in Qumran texts. The Pesher on Habakkuk, for example, assumed a deep correlation between contemporary circumstances, their religious significance, and absolute applicability to times and personalities.

\section{The Psalms}

The Psalms constitute the single largest consistent body of Old Testament texts used by New Testament writers-some 44 citations (not including allusions) which is the best sample size of any text genre in the New Testament. It may therefore be possible to trace developing methods of source citation and use by tracking the sort of exegetical burden New Testament writers placed on the Psalms. Although I am restricting myself to Pauline citations, clearly this needs to be extended to the entire corpus. I want to suggest some distinctives about the way sources were cited and whether midrash is the best category to explain it.

The first example is found in Paul's use of Psalm 68:18 in Ephesians 4:8 in which Paul appears to radically rework the text of the Psalm for purposes related to his teaching on church unity and the sort of charisms necessary to preserve and strengthen it. The work of Gary Smith disclosed a possible strategy used by Paul which can help explain the apparent lack of control in his use of Psalm 68. ${ }^{2}$

Ephesians 4:8 Therefore it is said, "When he ascended on high he led a host of captives, and he gave gifts to men".

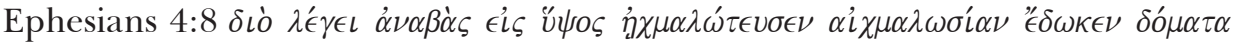

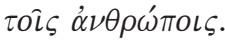

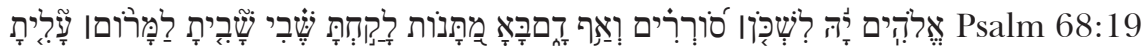

The LXX reading follows MT and it appears that Paul, rather than adopting a midrashic reading of the Psalm, has exegeted the Psalm in relation to the situation cal Society 18 (1975): 181-89.

PERICHORESIS $11.2(2013)$ 
depicted in Ephesians 4, that is, the charisms for ministry in the church. Although G. B. Caird argued for targumic influence in Paul's reading ${ }^{3}$ clearly, Paul is not offering commentary to explain a difficult text but rather using a text to validate his teaching on the theological origins of Christian unity and the patterns of charismata that empower the sort of ministries that secure it. But the burden of proof in Paul's mind lies in the existence of a paradigm for ministry that can be tapped for its divine origins. This yields the necessary credibility for his teaching. Paul achieves his reading of Psalm 68 by exegeting the text and folding his exegesis into the Psalm as he quotes it. The Psalm is itself, at these verses, is a deliberation on Numbers 8:6-9, 18:6 where the giving and receiving of the Levites from and back to Israel is understood to be the gift of God to Israel. This creates a skillful and non-contradictory tension since the "gifts" and "captives" are one and the same, just as "receiving" and "giving". In Paul's re-contextualisation, the Levites are taken from within the congregation and returned to it as divine gift. Paul may be nudging towards a pesher reading of Psalms 68 and Numbers 8, 18 but the question of a text's fulfillment for Paul resides in the actual exegetical appropriateness that links its context with the new one. However, Paul does not press the texts beyond their historical potential into the realm of deeper or simply associative meaning. Paul does not strip the text of its original purpose which is his main control. He has only gone so far as to embrace what he takes to be the original intent of his source texts. His exegesis has preserved the meaning of the texts and reshaped them subtly to yield a fresh but consistent application which lay within the spirit of the original and thus sustained their authoritative character. Thus in Psalm 68, the burden of the text is God's victory over the nations, the resultant blessing of Israel, and the giving and receiving of gifts (the Levites of Numbers 8), for the unity of Israel and the establishment God's presence among the people. As a Psalm with eschatological themes, this resonated with Paul's own belief that Christ was not simply a new Moses that "ascended the mount" but "God with us" which is what Psalm 68 anticipates-perhaps echoing the new creation where God dwells with his new people, a redefinition of Israel that embraces old Israel but is not a mere escalation of its formative identity in Moses but the actual presence of God in Christ. God ascends Zion in the Psalm an action Paul identifies with Christ. The new Levites are the people of God who have been given various tangible spiritual gifts to bring integrity, continuity, and unity to the new Israel. Paul has folded Numbers 8 into his reading of Psalm 68 and so the exegesis is the translation he cites.

At Romans 3:9-18, Paul reproduces a constellation of texts from the Psalms and also some verses from Isaiah 59:7-8. The burden of these verses is the univer- 
sality of sin and Paul has piled up a large number of texts that stress this. Romans 3:14 quotes a portion of Psalm 10:7.

${ }^{9}$ What then? Are we Jews any better off? No, not at all; for I have already charged that all men, both Jews and Greeks, are under the power of $\sin ,{ }^{10}$ as it is written: "None is righteous, no, not one; ${ }^{11}$ no one understands, no one seeks for God. ${ }^{12}$ All have turned aside, together they have gone wrong; no one does good, not even one". ${ }^{13}$ "Their throat is an open grave, they use their tongues to deceive". "The venom of asps is under their lips". ${ }^{14}$ "Their mouth is full of curses and bitterness". ${ }^{15}$ "Their feet are swift to shed blood, ${ }^{16}$ in their paths are ruin and misery, ${ }^{17}$ and the way of peace they do not know".

18“There is no fear of God before their eyes".

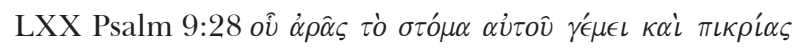

Romans 3:14 $\hat{\omega} \nu+$ disturbed word order.

Paul's use of the first half of LXX Psalm 10:7 is consistent with the theme he develops in Romans 3, which is the universality of human sin and rebellion. However, the Psalm itself addresses the condition of the individual, the "wicked man", (singular) which Paul, by the replacement of the singular relative pronoun hou with the plural, easily extends to all humanity. He does this with minimal textual distortion while remaining linked to the Psalm's original intent. Again, he achieves this not by interpreting the text beyond its intentional limits but by folding his wider theme into his actual citation of the Psalm suggesting a more fluid, flexible, yet disciplined attitude towards the letter of the text. Indeed, he has altered his vorlage, and yet he has not altered the focus of that text.

In 1 Corinthians 3:20, Paul quotes Psalm 94:11.

Psalm 94:11 the LORD, knows the thoughts of man, that they are but a breath.

$$
\text { MT }
$$

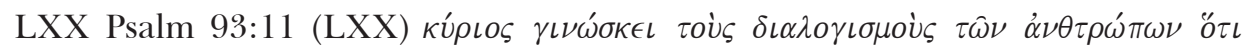

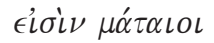

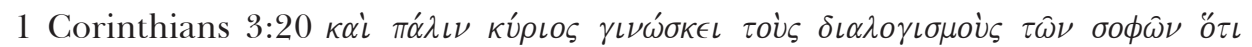
$\epsilon i \sigma i \nu \mu \dot{\alpha} \tau \alpha \iota \circ \iota$

There is no reading from MT to justify $\sigma o \phi \hat{\omega} \nu$ instead of $\dot{\alpha} \nu \theta \tau \rho \omega \dot{\omega} \pi \omega \nu$ and LXX follows MT. So Paul must have changed his exemplar. Why has he done this? The context of 1 Corinthians is the contrast between divine wisdom and human wisdom. Earlier, Paul determined that "the foolishness of God is wiser than man..." (1 Corinthians 2:25a). Here, Paul has occasion to discipline the Corinthians who privilege an esoteric spiritual wisdom apparently with claims to mystical 
knowledge. However, the actions of the church were distinctly at variance with this claim, including the toleration of incest, drunkenness, and manifest disunity within the Body. Their charismatic wisdom, to continue the juxtaposition, was actually ignorance. So Paul is constrained to evaluate their claims to wisdom and in so doing, draws on traditional Jewish theology which constrasted human thoughts and values with those of the divine councils. See, for example, 1 Maccabees 2:61ff; Baruch 3:29ff; Targum on Job. Paul's use of Psalm 94 is contextually correct-the Psalm deliberates divine judgement on all human arrogance and claims to special knowledge. The verses further discuss the redemption of those who are the victims of such claims in that they exalt the covenant faithfulness of God toward the righteous. Since the Corinthians exalt Sophia, though they do so unwisely, Paul considers the Psalm and in these verses, interprets it with respect to the Corinthian situation. His interpretation then becomes part of his actual citation, evidently with no sense of violence being done to the letter of the text, because the dynamic intention of the original text has been maintained, in effect skipping a step.

In Romans 11:9 Paul quotes Psalms 69(68):22-23(23-24) where he discusses the fate of Israel in the eschatological counsels of God. Paul has been scathing of Israel's rejection of God and yet asks if this means God has also rejected Israel. He concludes that while the elect and remnant of Israel obtained the grace of God, as a whole, the nation did not (Romans 11:7). His question then is why this happened and whether the situation is permanent? At Romans 11:9, Paul thinks their condition happened because what was a source of divine favour (somehow) led to a condition of blindness.

Romans 11:9 And David says, "Let their table become a snare and a trap, a pitfall and a retribution for them..."

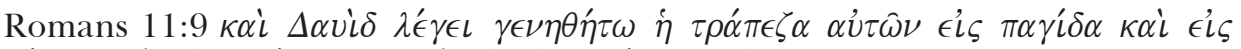

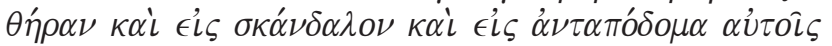

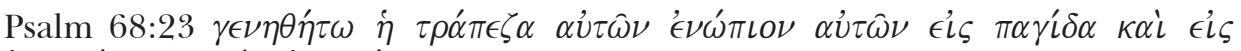

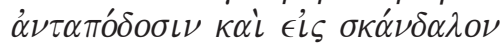

Psalm 69:22 Let their own table before them become a snare; let their sacrificial feasts be a trap.

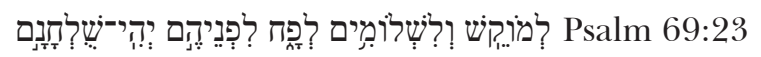

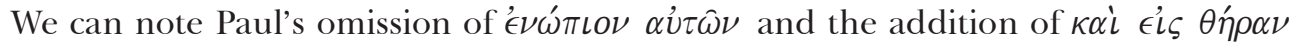
and his subsequent reversed word order of LXX. LXX expands MT and Paul ex-

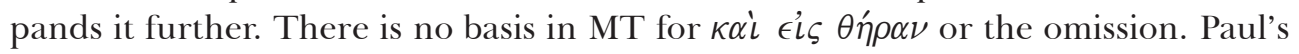
citation seems to address greater poetic balance poetic balance in LXX while at the same time heightening the theological point in question. The changes made to 
Paul's exemplar are slight and perhaps of no great consequence in the final analysis but again, they point to a creative method of handling texts which is not midrashic but epexegetical and folds the text's interpretation back into the text yet without damaging its intention. It is a fine line but signals Paul's restraint.

But is Paul doing something unique or is a new way of using Scripture emerging in the New Testament? As a final example from Hebrews, obviously not Pauline, Psalm 40(39):6-8(7-9) is quoted at Hebrews 10:4-6.

${ }^{4}$ For it is impossible that the blood of bulls and goats should take away sins. ${ }^{5}$ Consequently, when Christ came into the world, he said, "Sacrifices and offerings thou hast not desired, but a body hast thou prepared for me; ${ }^{6}$ in burnt offerings and sin offerings thou hast taken no pleasure".

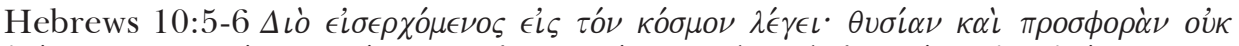

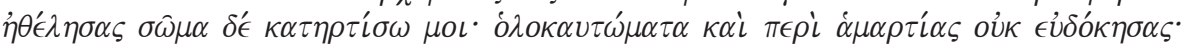

Psalm 40:6-8 "Sacrifice and offering thou dost not desire; but thou hast given me an open ear. Burnt offering and sin offering thou hast not required. ${ }^{7}$ Then I said, 'Lo, I come; in the roll of the book it is written of me; ${ }^{8}$ I delight to do thy will, O my God; thy law is within my heart"”.

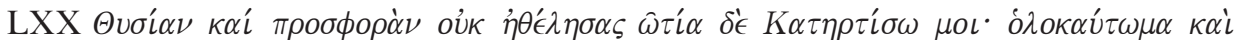

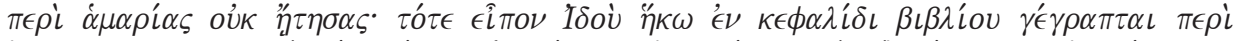

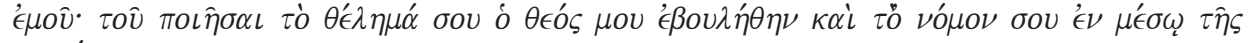

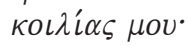

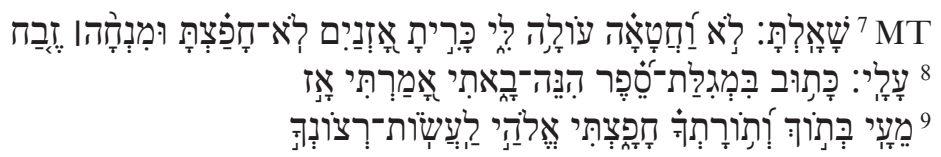

At Hebrews 10:5, the text cannot be following MT at $\sigma \omega \mu \alpha$ (LXX follows MT) and it must be assumed that the author has intentionally exegeted the text within the process of translation. Thus the author of Hebrews has further corrected his LXX

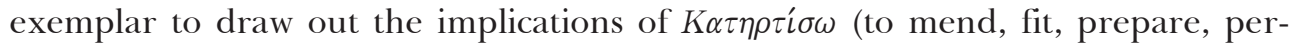
fect) translating (ָָָּריתָ (to dig). What is happening here? Has the author of Hebrews been negligent or simply reached for a text through idea association alone while summarily altering the Scripture he quotes regardless of its intent?

The difference is clear:

Hebrews 10:5-6 Sacrifices and offerings thou hast not desired, but a body hast thou prepared for me;

PERICHORESIS $11.2(2013)$ 
Psalm 40:6-8 Sacrifice and offering thou dost not desire; but thou hast given me an open ear. Literally, "dug for me an ear".

Is there an exegetical purpose behind what seems to be the author's dramatic alteration of both LXX and MT (recalling LXX follows MT at this point)? If we follow the approach used in the Pauline examples and consider Psalm 40 overall, verses 1-10 depict a theme of individual praise and thanksgiving, while verses 11-17 constitute a plea for deliverance-an individual lament. The verses quoted in Hebrews come from the first section of the Psalm and align with Hebrews' purpose of demonstrating the superiority of the new covenant in Christ by contrasting its permanent and final character with the temporary nature of the old covenant. The focus of this argument is the inadequacy of the sacrificial system for the removal of sin and the re-establishment of normalised relations between individuals, the nation, and God. Such a view is well-established in both biblical and extrabiblical literature. ${ }^{4}$ The intricacy of Hebrews' source citations is well-known, ranging from direct quotation to allusion, to arguments that turn on a single word. ${ }^{5}$ In the present case, how has the Psalms' "ear" become Hebrews' "body"? Even as a metaphor and by a process of inner exegesis in which to "dig with the ear" is RSV's "given me an open ear" that is, submissive and teachable,${ }^{6}$ the move to "a body" is a considerable leap. I suggest this is consistent with Hebrews' Christology in which the Son learns obedience, submits himself to doing God's will and accepts God's discipline. In so doing he is shown worthy of his high priestly status. He did what the ideal priest or king was required to do, conceivably "after the order of Melchizedek". But there is more to this. Hebrews 10:5 assigns these words to Christ "when [he] came into the world" as an allusive reference to the incarnation. That is, "the word became flesh and dwelt among us" which in terms of the theological style of Hebrews is analogous to 10:5b, "a body hast thou prepared for me". The submission of Christ, his kenosis, is indelibly linked to his incarnation. That was the first act of obedience and the first step towards fulfillment of the will of God. As such, it is a crucial piece of Hebrews' extensive argument that the Christ is Jesus. What the writer of Hebrews has done is exegete Psalm 40, creatively applied the results to his Christology and with relatively little intrusion, located those results in his reading of the Psalm. To be sure, it appears to be a major de-

For example, 1 Samuel 15:22; Psalm 50:8-11; Isaiah 1-10-13; Jeremiah 7:21-24; Hosea 6:6; 2 Enoch 45:3; Sirach 34:18-35:12. Also note the dialogue at Mark 12:28-34 which makes the same point. The basis for forgiveness of sins continued to be a live question in Israel's tradition, and was of necessity re-contextualised following the destruction of Jerusalem. George H. Guthrie, "Hebrews", in Commentary on the New Testament Use of the Old Testament, eds. G. K. Beale and D. A. Carson (Grand Rapids: Baker Academic, 2007), 919-95.

6 The term פָּרָ is idiomatic. Craigie points to Deuteronomy 17:14-20 as the referent in Psalm 40:7. Peter C. Craigie, Psalms 1-50, volume 19 of Word Biblical Commentary, gen. eds. David A. Hubbard and John D. Watts (Waco, TX: Word Books, 1983), 315. 
parture from the LXX perhaps a misquote, but it is not arbitrary and, importantly, sustains the original intent. It may be true that this sort of process reaches new heights in Hebrews but I suggest it remains on the same trajectory as Paul. The new reality that has been understood to have occurred in Jesus of Nazareth has necessitated a further disciplined projection of rabbinic exegesis and the quotation of Scripture. The point to be made here is that while some source citations appear quite cavalier, there is evidence of extremely creative, subtle, and yet disciplined use of such texts. The reason is the object of the respective authors' concerns and, it may be said, the general defensibility of the citations in their rhetorical strategy. If citations were employed in an arbitrary way, their use could only be described as either self-serving or whimsical. The New Testament writers were not interested in resolving Scriptural anomalies. However, the author of Hebrews, at least in this situation, has demonstrated not only an extremely detailed familiarity with Scripture, but also a very sophisticated capacity to use it rhetorically with effect. In so doing, the result is a powerful Christology which locates itself in the ontology of Scripture as the word of God.

Hebrews, at least in these few verses, handled Scripture as Paul did-perhaps with even greater creativity. The text was exegeted with a close view as to its origi-

nal intent well before its potential for application was fully exploited in the new context of incarnation and fulfillment.

\section{Bibliography}

Caird, G. B. "The Descent of Christ in Ephesians 4:7-11". Studia Evangelica II (1964).

Craigie, Peter C. Psalms 1-50, volume 19 of Word Biblical Commentary. General editor David A. Hubbard and John D. Watts. Waco, TX: Word Books, 1983.

Ellis, E. Earle. Paul's Use of the Old Testament. Reprinted from 1957. Grand Rapids: Baker Book House, 1981.

Evans, C. F. "The New Testament in the Making". In The Cambridge History of the Bible, volume 1. Edited by P. R. Ackroyd. Cambridge: Cambridge University Press, 1980.

Guthrie, George H. "Hebrews". Commentary on the New Testament Use of the Old Testament. Edited by G. K. Beale and D. A. Carson, 919-95. Grand Rapids: Baker Academic, 2007.

Smith, Gary V. "Paul's Use of Psalm 68:18 in Ephesians 4:8”. Journal of the Evangelical Theological Society 18 (1975): 181-189. 